\title{
Development of Interactive Learning Based Discovery Learning to Improve Mathematic Representation and Self-Efficacy Abilities of MAN 1 Medan Students
}

\author{
Maulida Hafni ${ }^{1}$, Edi Syahputra ${ }^{2}$, Nerli Khairani ${ }^{3}$ \\ 1, 2,3 Mathematics Education Study Program, Postgraduate, State University of Medan, \\ Jl. William Iskandar Pasar V Medan Estate, Medan, Indonesia, 20221 \\ lidahafni@gmail.com
}

\begin{abstract}
This study aims to: 1) Finding interactive learning with discovery learning that are valid, practical and effective in improving students' mathematical representation skills and self-efficacy; 2) Describe the increase in students' mathematical representation ability using interactive learning with discovery learning; 3 ) Describe the increase in students' self-efficacy abilities by using interactive learning with discovery learning. This research is a development research conducted in two stages, namely the first stage of developing interactive learning through the discovery learning using the Thiagarajan 4-D development model and the second stage of testing the interactive learning through the discovery learning model developed in class X IIS 1 and X IIS 2 MAN 1 Medan. From the results of trial I and trial II obtained: 1) the learning device through the discovery learning model developed has met the valid, practical and effective criteria in terms of their respective criteria; 2) the achievement of students' mathematical representation ability using learning devices with discovery learning model increased, in terms of posttest classical completeness of the first trial of $68.75 \%$ increased to $87.50 \%$ in the second trial; 3) the ability of students' self-efficacy to use learning devices with the discovery learning model approach increased, in terms of the classical completeness of the posttest trial I by $68.75 \%$, increasing to $87.50 \%$ in the second trial.
\end{abstract}

Keywords: interactive learning, discovery learning, mathematical representation ability, self-efficacy

\begin{abstract}
Abstrak
Penelitian ini bertujuan untuk: 1) Menemukan pembelajaran interaktif berbasis discovery learning yang valid, praktis dan efektif dalam meningkatkan kemampuan representasi matematis dan self efficacy siswa; 2) Mendeskripsikan peningkatan kemampuan representasi matematis siswa dengan menggunakan pembelajaran interaktif berbasis discovery learning; 3) Mendeskripsikan peningkatan kemampuan self-efficacy siswa dengan menggunakan pembelajaran interaktif berbasis discovery learning. Penelitian ini merupakan penelitian pengembangan yang dilakukan dalam dua tahap, yaitu tahap pertama pengembangan pembelajaran interaktif melalui model pembelajaran discovery learning dengan menggunakan model pengembangan 4-D Thiagarajan dan tahap kedua mengujicobakan pembelajaran interaktif melalui model pembelajaran discovery learning yang dikembangkan di kelas X IIS 1 dan X IIS 2 MAN 1 Medan. Dari hasil uji coba I dan uji coba II diperoleh: 1) pembelajaran interaktif melalui model pembelajaran discovery learning yang dikembangkan telah memenuhi kriteria valid, praktis dan efektif ditinjau dari kriteria masing-masing; 2) pencapaian kemampuan representasi matematis siswa menggunakan perangkat pembelajaran dengan model pembelajaran discovery learning meningkat, ditinjau ketuntasan klasikal posttest uji coba I sebesar 68,75\% meningkat menjadi $87,50 \%$ pada uji coba II; 3) kemampuan self efficacy siswa menggunakan perangkat pembelajaran dengan pendekatan model pembelajaran discovery learning meningkat, ditinjau dari ketuntasan klasikal posttest uji coba I sebesar $68,75 \%$ meningkat menjadi $87,50 \%$ pada uji coba II.
\end{abstract}

Kata kunci: pembelajaran interaktif, discovery learning, kemampuan representasi matematis, self-efficacy

Copyright (c) 2021 Maulida Hafni, Edi Syahputra, Nerli Khairani

Corresponding author: Maulida Hafni

Email Address: lidahafni@gmail.com (Jl. William Iskandar Pasar V Medan Estate, Medan, Indonesia, 20221)

Received 05 April 2021, Accepted 15 April 2021, Published 07 May 2021

\section{INTRODUCTION}

In the world of education, schools have an important role in equipping and shaping students' mathematical knowledge in the future(S. N. Dewi, Wijaya, Budianti, \& Rohaeti, 2018; Dini, Wijaya, \& Sugandi, 2018) . Basic concepts in mathematics must also be implanted in the minds of students (D. P. Dewi, Mediyani, Hidayat, Rohaeti, \& Wijaya, 2019; T.T. Wijaya, Purnama, \& Tanuwijaya, 2020; T.T. Wijaya, Ying, \& Purnama, 2020). To achieve this, the teacher as the main actor in the learning process 
in the classroom is the main potential for educational development, it is better if teachers should develop their potential at any time in order to improve the quality of learning (T.T. Wijaya, Jianlan, \& Aditya, 2020). There are so many ways that can be taken to improve the quality of learning, one of which is the use of learning designs (T.T. Wijaya \& Hermita, 2021). Rahmawati (2016) one of the things that is influential in effective learning is learning designs that are made according to the needs of students and carried out in order to achieve learning objectives. For that teachers need to develop interactive learning. According to Wahab (2016) Interactive learning is a method or learning technique that is used by the teacher when presenting learning materials, the teacher plays the main role in creating educational interactive situations, namely the interaction between teacher and student, student and student and with learning resources to support the achievement of learning objectives Interactive learning is also a process of interaction learning between teachers and students, students and students or between students and their environment. Through the process of interaction, it is possible for students' abilities to develop mentally and intellectually.

In line with this, Ali (2014) states that "interactive learning emphasizes the discussion process so that learning outcomes are obtained through interactions between students and teachers, students and students, as well as interactions between students and the material being studied, and between students' thoughts and the environment." It should be remembered and noted that humans, especially students, can absorb material / learning / knowledge if the knowledge is conveyed and packaged in an attractive and impressive form, so that the learning they see will continue to be remembered in their minds.

According to England, Elaine and Finney, Andy (2002) said that "Interactive Media is the integration of digital media including a combination of electronic text, graphics, moving images, and sound, into a structured digital environment that can make people interact with data for the purpose of right". In connection with technological developments, the existing learning media has also developed. Many media are developed using the help of technology. One of the growing media is known as multimedia. multimedia learning is a medium that is able to involve many senses and organs during the learning process (T T Wijaya, Ying, et al., 2020; Tommy Tanu Wijaya, Ying, \& Purnama, 2020; Zhang, Zhou, \& Wijaya, 2020).

The fact is in the field, based on data from BPS (Badan Pusat Statistik, 2018) a survey of the use and utilization of information and communication technology in the education sector was conducted on 4,014 schools spread across 34 provinces. Based on the level of education, SD and equivalent are 64,55 percent, junior high school and equivalent are 19,22 percent and SMA and equivalent are 16,23 percent. This shows that the use of multimedia as a learning tool is rarely used.

Then based on the results of observations made at MAN 1 Medan, it turns out that the school has facilities that support developing multimedia learning. For example computers, separate computer labs, each class has access to learning using media and so on. However, based on direct interviews with school principals, it turns out that around $80 \%$ of teachers have not used the facilities available at the school. Then the next stage was carried out a survey in several class $X$ which were randomly selected, it turned 
out that there was an interesting fact that $73 \%$ of class $\mathrm{X}$ students answered that mathematics was difficult to understand and the formula was difficult. Even though when interviewed, the students answered that mathematics was not a difficult subject. In addition, 38\% of them also answered that their textbooks were not interesting to study. The mathematics books that are used by students today use a way of conveying by telling a long story, then students are given a lot of questions. That way students will be bored with learning and do not understand explanations and questions so that in the end students find it difficult to answer these questions.

Mathematical representation, which is one of the competencies, is an aspect that is always present in learning mathematics. Representative ability is a mathematical ability by expressing mathematical ideas (problems, statements, definitions, etc.) in various ways (Syafri, 54: 2017). The representation or model of a mathematical situation or concept when presented in a ready-made form can actually be seen as reducing or negating the opportunity for students to think creatively and discover early on the mathematical concepts contained in a problem situation.

Mustangin (2015) states that the various representations that are often used in communicating mathematics include visual presentations such as tables, pictures, graphs; mathematical statement or mathematical notation; and written texts written in their own language, both formal and informal, or a combination of all of them. Learning mathematics in class should provide sufficient opportunities for students to practice and develop mathematical representation skills (Sabirin, 2014). In the research results expressed by Zazkis and Liljedahl (2004) show that the ability to understand and represent students who are intelligent is the key to getting the right problem-solving solution.

Regarding learning, of course, it is hoped that students have high self-efficacy, meaning that students have high confidence that they are able to complete their lesson assignments and overcome various problems related to the lesson.

Self-efficacy is very important because high self-efficacy abilities will cause someone not only to try to get something or the knowledge needed, but they will find other knowledge related to the task or job they are doing and they are very motivated to get it. the results of a better and more perfect work (Schunk, DH, 1995: 113). Several studies have shown that self-efficacy is important in determining academic achievement. For example, Bouchey and Harter (2005: 677) state that the level of student selfefficacy will greatly affect the learning outcomes they get in a particular field. A student who feels capable of doing something will have an impact on the success of the student in completing what he is doing.

Overcoming the problems raised above, especially those related to mathematical representations, self-efficacy and learning devices, it is necessary to make efforts to choose the right strategy and learning model and can support learning success. One of the lessons that can be a solution to the problems above is the learning model through discovery (Discovery Learning). Learning through discovery includes the following six steps, namely: (1) stimulation, (2) problem statement (statement / identification of 
problems), (3) data collection, (4) data processing. (5) verification (proof) (6) generalization (draw conclusions or generalizations).

Based on the overall background description, researchers are interested in conducting research related to interactive learning, discovery learning models, students' mathematical representation abilities, and self-efficacy entitled "Development of Interactive Learning Based on Discovery Learning to Improve Mathematical Representation Ability and Self-Efficacy of MAN Students. 1 Medan”.

\section{METHODE}

\section{Research Design}

This type of research is Development Research, using the Thiagarajan, Semmel and Semmel learning devices development model, namely the 4-D model (define, design, develop, and disseminate). In this study, it is centered on developing interactive learning through the discovery learning model of trigonometric material.

\section{Subject and Object of Research}

The subjects in this study were students of class X MAN 1 Medan in the academic year 2020/2021 in class X IIS 1 and X IIS 2, while the object in this study was interactive learning through discovery learning models on trigonometric material to improve Mathematical Representation skills (TKRM). and student self-efficacy questionnaires.

\section{Instrument}

The learning devices that will be produced are learning implementation plans, student books, teacher books, student worksheets, tests of mathematical representation abilities and self-efficacy questionnaires.

\section{Data Analysis Technique}

Before the post-test of the mathematical representation ability was used in the first trial and the second trial, the mathematical representation ability test instrument was first tested outside the sample class, then the test results were analyzed for validity and reliability. The way to analyze the practicality of learning devices is by providing interactive learning devices to the validator for validation. The effectiveness of learning devices related to the mathematical representation ability is determined based on the classical achievement of student learning completeness. And the data obtained from the test results were analyzed to determine the increase in students' mathematical representation abilities. The scores obtained by students before and after using the learning devices that have been developed were analyzed by comparing student scores obtained from student test results before and after being given treatment.

The formula used to calculate validity is the Product Moment correlation formula:

$$
r_{X Y}=\frac{N \sum X Y-\left(\sum X\right)\left(\sum Y\right)}{\sqrt{\left.\left\{N \sum X^{2}-\left(\sum X\right)^{2}\right\} N \sum Y^{2}-\left(\sum Y\right)^{2}\right\}}}
$$


(Arikunto, 2013: 213)

\section{Information:}

$\mathrm{N} \quad=$ the number of research respondents

$\Sigma \mathrm{X}=$ the total score of the variable $\mathrm{X}$

$\Sigma \mathrm{Y} \quad=$ the total score of the variable $\mathrm{Y}$

$\Sigma X Y=$ the sum of the multiplication of the scores of the $\mathrm{X}$ and $\mathrm{Y}$ variables

$\Sigma \mathrm{X}^{2}=$ the sum of squares of the variable score $\mathrm{X}$

$\Sigma \mathrm{Y}^{2}=$ the sum of squares of the $\mathrm{Y}$ variable score

$\mathrm{r}_{\mathrm{xy}} \quad=$ the value of the correlation coefficient for the variables $\mathrm{X}$ and $\mathrm{Y}$

Guidelines for interpreting the validity of the test according to Arikunto (2013: 89) as in Table 1.:

Table 1. Interpretation of Validity on Test

\begin{tabular}{|c|c|c|}
\hline No & Interpretation & Criteria \\
\hline 1 & $0,80-1,00$ & Very High \\
\hline 2 & $0,60-0,80$ & High \\
\hline 3 & $0,40-0,60$ & Medium \\
\hline 4 & $0,20-0,40$ & Low \\
\hline 5 & $0,00-0,20$ & Very Low \\
\hline
\end{tabular}

Then to determine the significance of the correlation obtained, tested with the $t$ test:

$$
t=r_{x y} \sqrt{\frac{N-2}{1-r_{x y}{ }^{2}}}
$$

Information:

$\mathrm{t}$ : Differential power $\mathrm{t}$ test

$\mathrm{N}$ : Number of subjects

$r_{\mathrm{xy}}:$ Correlation coefficient

To determine whether a test item is valid or not, it is necessary to compare tcount with ttable. Meanwhile, to determine the t-table, the Product Moment correlation table is used by looking at $\mathrm{df}=\mathrm{N}$ -2 and a significant level of $5 \%$ or 0,05 with the interpretation $t_{\text {count }} \geq t_{\text {table }}$ so the correlation is significant. The reliability of the test instrument is calculated to determine the determination of the test results. According to Arikunto (2013: 221) to calculate the reliability coefficient of the items used the Alpha formula is as follows:

$$
r_{11}=\left(\frac{k}{(k-1)}\right)\left(1-\frac{\sum \sigma_{h}^{2}}{\sigma_{t}^{2}}\right)
$$

Information:

$r_{11}:$ Test reliability coefficient

$\mathrm{K}$ : The number of items

$\sum \sigma_{h}^{2}:$ The sum of the variance in the score for each test item

$\sigma_{t}^{2} \quad$ : Total variance 
To interpret the reliability coefficient of an evaluation tool (Arikunto, 2013: 221) provides criteria such as Table 2. The following:

Table 2. Reliability Interpretation of Test instruments

\begin{tabular}{|c|c|c|}
\hline No & Interpretation & Criteria \\
\hline 1 & $0,00<r_{x y} \leq 0,20$ & Very Low \\
\hline 2 & $0,20<r_{x y} \leq 0,40$ & Low \\
\hline 3 & $0,40<r_{x y} \leq 0,60$ & Medium \\
\hline 4 & $0,60<r_{x y} \leq 0,80$ & High \\
\hline 5 & $0,80<r_{x y} \leq 1,00$ & Very High \\
\hline
\end{tabular}

To see the achievement of the learning objectives for each item on the mathematical representation ability test, a formula is used (Trianto, 2011):

$$
\mathrm{T}=\frac{\text { Total student scores for item } \mathrm{i}}{\text { The maximum number of scores in item } \mathrm{i}} \times 100 \%
$$

The criteria are:

$$
\begin{aligned}
& 0 \% \leq \mathrm{T}<75 \% \quad \text { : Learning objectives have not been achieved } \\
& 75 \% \leq \mathrm{T} \leq 100 \% \quad \text { : Learning objectives achieved }
\end{aligned}
$$

The data from the student response questionnaire were analyzed using qualitative descriptive by presenting the positive and negative responses of students in filling out the student response questionnaire sheets which were calculated using the formula (Trianto, 2011):

$$
\mathrm{PRS}=\frac{\sum \mathrm{A}}{\sum \mathrm{B}} \mathrm{x} 100 \%
$$

Keterangan:

PRS : Percentage of students who responded positively to each category being asked

$\sum \mathrm{A} \quad$ : The proportion of students who vote

$\sum B \quad$ : Number of students (respondents)

The following is the flow of research carried out in the field shown in Figure 1.

\section{RESULTS AND DISCUSSION}

\section{The validity of interactive learning developed with discovery learning models}

It can be concluded that the validation results for each component of interactive learning devices through the discovery learning model developed are in the "valid" category with an average value of each component, namely: Learning Implementation Plan (4,33); Teacher's Book (4,24); Student Books $(4,31)$ and student worksheets $(4,33)$. But even though the components of the learning device developed have met the validity criteria, there are a number of things that must be improved according to the notes provided by the expert team, including the use of language, writing or typing and display of images that 
Development of Interactive Learning Based Discovery Learning to Improve Mathematic Representation and Self-Efficacy Abilities of MAN 1 Medan Students, Maulida Hafni, Edi Syahputra, Nerli Khairani

must be in accordance with the conditions of the material. So based on the results of notes from experts that this learning tool has met the validity criteria with the "valid" category with a note of little revision or no revision.



Figure 1. The Interactive Learning Development Research Procedure through the Discovery Learning Learning Model 


\section{The Practicality of Interactive Learning Developed with Discovery Learning Models}

From the results of the expert validation and the results of the interviews, it can be concluded that interactive learning through the discovery learning model that has been developed is "practical" to be used in learning.

\section{The effectiveness of interactive learning developed with the Discovery learning model}

Based on the results of trial I and trial II, interactive learning through the discovery learning model that was developed has met the effective category in terms of: (1) classical student learning completeness; (2) achievement of learning objectives; (3) student response and (4) learning time. In the following, we will present a discussion for each indicator in measuring the effectiveness of interactive learning developed with a discovery learning model.

Furthermore, the classical completeness results of students' mathematical representation abilities in the first trial can be seen in table 3. below:

Table 3. Classical Completeness Levels of Mathematical Representation Ability in Trial I

\begin{tabular}{|c|c|c|c|c|}
\hline \multirow[b]{2}{*}{ Category } & Pretest & \multirow{2}{*}{$\begin{array}{c}\text { Classical } \\
\text { Completeness } \\
\text { Percentage }\end{array}$} & Posttest & \multirow{2}{*}{$\begin{array}{c}\text { Classical } \\
\text { Completeness } \\
\text { Percentage }\end{array}$} \\
\hline & Total Students & & Total Students & \\
\hline Complete & 17 & $53,13 \%$ & 22 & $68,75 \%$ \\
\hline Not Complete & 15 & $46,87 \%$ & 10 & $31,25 \%$ \\
\hline Total & 32 & $100 \%$ & 32 & $100 \%$ \\
\hline
\end{tabular}

Based on the data in table 2. above, it can be seen that the classical completeness of the results of the students' mathematical representation ability in the pretest first trial was 53,13\%, while in the posttest trial I was $68,75 \%$. Furthermore, the results of classical student learning completeness for students' mathematical representation abilities in the second trial can be seen in table 4. below:

Table 4. Classical Completeness Levels of Mathematical Representation Ability in Trial II

\begin{tabular}{|c|c|c|c|c|}
\hline \multirow[b]{2}{*}{ Category } & Pretest & \multirow{2}{*}{$\begin{array}{c}\text { Classical } \\
\text { Completeness } \\
\text { Percentage }\end{array}$} & Posttest & \multirow{2}{*}{$\begin{array}{c}\text { Classical } \\
\text { Completeness } \\
\text { Percentage }\end{array}$} \\
\hline & Total Students & & Total Students & \\
\hline Complete & 21 & $65,63 \%$ & 28 & $87,50 \%$ \\
\hline Not Complete & 11 & $34,37 \%$ & 4 & $12,50 \%$ \\
\hline Total & 32 & $100 \%$ & 32 & $100 \%$ \\
\hline
\end{tabular}

Based on the data in table 3. above, it can be seen that the classical completeness of the results of the mathematical representation ability of students in the pretest first trial was $65,63 \%$, while in the posttest trial I was $87,50 \%$.

Then, the description of the results of students' self-efficacy abilities in the first trial is shown in table 5 . 
Table 5. Description of the Results of Student's Self-efficacy Ability in Trial I and Trial II

\begin{tabular}{|c|c|c|c|c|}
\hline \multirow{2}{*}{} & \multicolumn{2}{|c|}{ Trial I } & \multicolumn{2}{c|}{ Trial II } \\
\cline { 2 - 5 } & $\begin{array}{c}\text { Pretest of } \\
\text { Mathematical } \\
\text { Self-efficacy } \\
\text { Ability }\end{array}$ & $\begin{array}{c}\text { Posstest of } \\
\text { Mathematical } \\
\text { Self-efficacy } \\
\text { Ability }\end{array}$ & $\begin{array}{c}\text { Pretest of } \\
\text { Mathematical } \\
\text { Self-efficacy } \\
\text { Ability }\end{array}$ & $\begin{array}{c}\text { Posstest of } \\
\text { Mathematical } \\
\text { Self-efficacy } \\
\text { Ability }\end{array}$ \\
\hline highest score & 72,22 & 86,11 & 83,33 & 94,44 \\
\hline Lowest score & 41,67 & 52,78 & 52,78 & 63,89 \\
\hline Average & 61,99 & 73,09 & 71,53 & 81,34 \\
\hline
\end{tabular}

From table 4, it shows that the average mathematical self-efficacy of students on the pretest results is 61,99 and the posttest results are 73,09. The achievement of the posttest learning objectives of the mathematical representation ability in the first trial can be seen in table 6 .

Table 6. Achievement of Learning Objectives on Mathematical Representation Ability in Trial I and Trial II

\begin{tabular}{|c|c|c|c|c|c|}
\hline \multirow[b]{2}{*}{ No } & \multirow[b]{2}{*}{ Learning objectives } & \multicolumn{2}{|c|}{$\begin{array}{c}\text { Mathematical representation } \\
\text { ability of Trial I }\end{array}$} & \multicolumn{2}{|c|}{$\begin{array}{c}\text { Mathematical representation } \\
\text { ability of Trial II }\end{array}$} \\
\hline & & $\begin{array}{c}\% \\
\text { Achievement of } \\
\text { Learning } \\
\text { Objectives } \\
\end{array}$ & Information & $\begin{array}{c}\% \\
\text { Achievement of } \\
\text { Learning } \\
\text { Objectives } \\
\end{array}$ & Information \\
\hline 1. & \begin{tabular}{|l} 
- \\
Students are able to \\
determine the \\
concept of \\
congruence to \\
determine the \\
trigonometric ratio \\
of a right triangle
\end{tabular} & $71,88 \%$ & $\begin{array}{c}\text { Not } \\
\text { Achieved }\end{array}$ & $79,43 \%$ & Achieved \\
\hline 2. & \begin{tabular}{|l} 
Students are able to \\
explain the concept \\
of sine, cosine and \\
tangent \\
- Students are able to \\
solve problems \\
related to \\
trigonometric \\
comparisons (sine, \\
cosine and tangent)
\end{tabular} & $72,39 \%$ & $\begin{array}{c}\text { Not } \\
\text { Achieved }\end{array}$ & $76,30 \%$ & Achieved \\
\hline 3. & 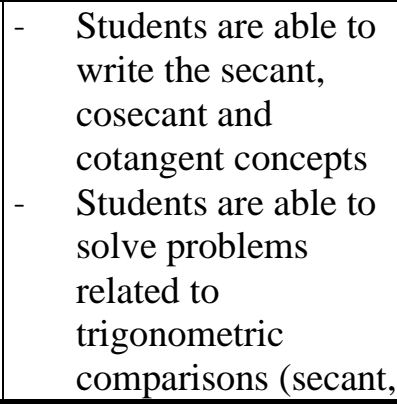 & $72,39 \%$ & $\begin{array}{c}\text { Not } \\
\text { Achieved }\end{array}$ & $84,38 \%$ & Achieved \\
\hline
\end{tabular}


cosecant and cotangent)

From table 5 above for the results of the mathematical representation ability of trial I, it can be seen that the achievement of the learning objectives in question number 1 was $71,88 \%$, the achievement of the learning objectives of question number 2 was obtained by 72,39\%, and the achievement of the learning objectives of question number 3 was obtained. obtained amounted to $72,39 \%$. While the results of the achievement of the learning objectives of each mathematical representation ability question in the second trial, the achievement of the learning objectives for question number 1 was $79,43 \%$; The achievement of learning objectives for question number 2 was obtained by 76,30\%, and the achievement of learning objectives for question number 3 was obtained by $84,38 \%$.

The results of the achievement of learning time in trial I and trial II were three meetings or $3 \times 40$ minutes, when compared to conventional learning carried out so far, there is no difference between the achievement of interactive learning time with the discovery learning model in trial I and the achievement. conventional learning time. Thus the achievement of interactive learning time with discovery learning models in the first trial is the same as ordinary learning, namely three meetings or 6 $\mathrm{x} 40$ minutes. This is in accordance with the learning time criteria, namely the achievement of learning time is at least the same as conventional learning, thus the achievement of learning time in Trial I has been achieved.

\section{Improving Students' Mathematical Representation Ability by Using Learning Tool Development with the Discovery Learning Model}

The increase in students' mathematical representation ability can be seen from the average posttest results of the mathematical representation ability obtained by students in the first trial of $68,75 \%$, increasing to $87,50 \%$ in the second trial. Thus, there was an increase in students' mathematical representation ability by $18,75 \%$. This shows that the use of learning devices with the developed discovery learning model has an impact on increasing students' mathematical representation abilities.

The increase in students' mathematical representation ability is due to the interactive learning process developed using the discovery learning model starting with a problem, so that students can use their previous experience in understanding and solving mathematical problems. Problems are designed so that the learning process is more meaningful, so that it can be understood that the problems given can be used as a starting point in developing students' mathematical representation skills. Furthermore, the discussion conducted by students is a bridge between students helping each other in understanding the problem. This is in line with Ausubel's (Trianto, 2011) theory that meaningful learning is a process of linking new information to relevant concepts contained in a person's cognitive structure. In learning, it means that the learning process starts from a problem and the information construction process occurs. In other words, a knowledge will be meaningful to students if the learning process involves problems or is carried out with a discovery learning model. 


\section{Increasing Students' Self-efficacy Ability Using Learning Tool Development with Discovery Learning Model}

The increase in students 'self-efficacy abilities was seen from the average posttest results of students' self-efficacy abilities obtained by students in the first trial of $68,75 \%$, increasing to $87,50 \%$ in the second trial. Thus, there was an increase in the students' self-efficacy ability by $18,75 \%$. This shows that interactive learning developed using discovery learning models has an impact on increasing students' self-efficacy abilities.

The increase in students' self-efficacy ability is due to the learning process using learning devices with the discovery learning model starting with a problem, so that students can use their previous experience in understanding and solving mathematical problems. The problem is designed so that the learning process is more meaningful, so that it can be understood that the problems given can be used as a starting point in developing students' self-efficacy abilities. Furthermore, the discussion conducted by students is a bridge between students helping each other in understanding the problem. This is in line with Ausubel's (Trianto, 2011) theory that meaningful learning is a process of linking new information to relevant concepts contained in a person's cognitive structure. In learning, it means that the learning process starts from a problem and the information construction process occurs. In other words, knowledge will be meaningful to students if the learning process involves problems or is carried out with discovery learning models.

\section{CONCLUSION}

1. The interactive learning tool based on the Discovery Learning model has been validated by five experts, consisting of: (1) RPP validation results with a total average of 4,33; (2) the results of the validation of the Teacher's Book with a total average of 4,24; (3) the results of the validation of students' books with a total average of 4,31 ; (4) LAS validation results with a total mean of 4,33 ; and (5) validation of students' representation ability and self-efficacy tests can be used with small revisions and without revision, where the overall mean value is at a value of $4 \leq \mathrm{Va}<5$ so that the experts state that interactive learning through the Discovery Learning model that has been developed meets the category. "Valid".

2. Interactive learning devices that have been validated by experts, state that the devices developed can be applied or used in the field with little or no revision. In addition, through the ability of teachers to manage learning in good categories. Thus, it can be concluded that interactive learning through the Discovery Learning model that has been developed meets the "practical" category.

3. Interactive learning developed through the Discovery Learning model for representation ability has met the criteria of being effective, in terms of: (1) completeness of classical student learning has been achieved in trial II, namely 87,50\%; (2) the achievement of learning objectives has been achieved for each item in the second trial, namely question number 1 by 79,43\%, question number 2 by $76,30 \%$, and question number 3 by $84,38 \%$; Meanwhile, for the ability of self-efficacy: (1) 
classical student learning completeness was achieved in the second trial, namely $87,50 \%$; (2) the achievement of learning objectives has been achieved for each item in the second trial, namely question number 1 by $80,73 \%$, question number 2 by $81,51 \%$, and question number 3 by $81,77 \%$; (3) student response of $93,23 \%$ has shown a positive response to interactive learning through the Discovery Learning model developed; and (4) the learning time used does not exceed the usual learning time.

4. The ability of students' mathematical representation with interactive learning through the Discovery Learning model increased, in terms of: (1) classical completeness of the posttest trial I was $68,75 \%$, increasing to $87,50 \%$ in trial II; and (2) N-Gain in the first trial of 0,21 in the low category increased to 0.37 in the medium category in the second trial.

5. The ability of students' self-efficacy with interactive learning devices through the Discovery Learning model increased, in terms of: (1) classical completeness of the posttest trial I was $68,75 \%$, increasing to $87,50 \%$ in trial II; and (2) N-Gain in the first trial of 0,25 in the low category increased to 0,31 in the medium category in the second trial.

\section{ACKNOWLEDGMENTS}

The author would like to express his sincere gratitude and highest appreciation to all parties who have helped the author, especially parents and families who have supported the author in everything. Dear Prof. Dr. Edi Syahputra, M.Pd as the first supervisor and Dr. Nerli Khairani, M.Si as the second supervisor, as well as the principal as well as the teachers and administrative staff of MAN 1 Medan who gave permission and opportunity for the author to research the school.

\section{REFERENCES}

Ali, M. 2004 Guru dalam Proses Belajar Mengajar. Bandung: Sinar Baru Algesindo.

Arikunto, S. 2013. Prosedur Penelitian: Suatu Pendekatan Praktik. Jakarta: Rineka Cipta.

Badan Pusat Statistik. 2018. Statistik Penggunaan dan Pemanfaatan Teknologi Informasi dan Komunikasi. BPS RI: Jakarta.

Bouchey, H.A., dan Harter, S. 2005. Reflected Appraisals, Academic Self Perceptions, and Math/Science Performance During Early Adolescence. Journal Pesychology No 97 Vol 4.

Dewi, D. P., Mediyani, D., Hidayat, W., Rohaeti, E. E., \& Wijaya, T. T. (2019). Analisis Kemampuan Berpikir Kritis Matematis Siswa Smp Pada Materi Lingkaran Dan Bangun Ruang Sisi Datar. JPMI (Jurnal Pembelajaran Matematika Inovatif), 2(6), 371. https://doi.org/10.22460/jpmi.v2i6.p371378

Dewi, S. N., Wijaya, T. T., Budianti, A., \& Rohaeti, E. E. (2018). Pengaruh Model Teams Games Tournament Terhadap Kemampuan Pemahaman Matematik Siswa Kelas XI SMK di Kota Cimahi Pada Materi Fungsi Eksponen. WACANA AKADEMIKA: Majalah Ilmiah Kependidikan, 2(1), 99. https://doi.org/10.30738/wa.v2i1.2570

Dini, M., Wijaya, T. T., \& Sugandi, A. I. (2018). Pengaruh Self Confidence Terhadap Kemampuan 
Pemahaman Matematik Siswa Smp. Jurnal Silogisme, 3(1), 1-7.

England., Elaine., dan Finney, A. 2002. Interactive Media - What's that? Who's Involved?. Interactive Media UK: ATSF

Mustangin. 2015. Representasi Konsep dan Peranannya dalam Pembelajaran Matematika di Sekolah. Jurnal Pendidikan matematika, 1(1):15-21.

Rahmawati, E., dan Suhendri, H. 2016. Pengembangan Desain Pembelajaran Matematika Siswa Sekolah Dasar Kelas 6. Jakarta: Jurnal Formatif, 6(3): 184-196.

Sabirin, M. 2014. Representasi Dalam Pembelajaran Matematika. JPM IAIN Antasari. Volume 01 Nomor 02Januari -Juni 2014.

Schunk, D. H. 1995. Self-Efficacy, Motivation and Performance. Journal of Applied Sport Psychology.

Syafri, F. S. 2017. Kemampuan Representasi Matematis dan Kemampuan Pembuktian Matematika. Jurnal Edumath, Volume 3 Nomor 1, Januari 2017, Hlm. 49 -55.

Trianto. 2011. Mendesain Model Pembelajaran Inovatif-Progresif. Penerbit Kencana Prenada Media Group, Jakarta.

Wahab, R. 2016. Psikologi Belajar. Jakarta: PT RajaGrafindo Persada.

Wijaya, T.T., \& Hermita, N. (2021). What is TPMK? (1st ed.). Bandung, Indonesia: AE publishing.

Wijaya, T.T., Jianlan, T., \& Aditya, P. (2020). Developing an Interactive Mathematical Learning Media Based on the TPACK Framework Using the Hawgent Dynamic Mathematics Software. Emerging Technologies in Computing, 318-328. https://doi.org/10.1007/978-3-030-60036-5

Wijaya, T.T., Purnama, A., \& Tanuwijaya, H. (2020). Pengembangan Media Pembelajaran Berdasarkan Konsep Tpack pada Materi Garis dan Sudut Menggunakan Hawgent Dynamic Mathematics Software. JPMI - Jurnal Pembelajaran Matematika Inovatif, 3(3), 205-214. https://doi.org/10.22460/jpmi.v1i3.205-214

Wijaya, T.T., Ying, Z., \& Purnama, A. (2020). Using Hawgent dynamic mathematics software in teaching trigonometry. International Journal of Emerging Technologies in Learning, 15(10). https://doi.org/10.3991/ijet.v15i10.13099

Wijaya, T T, Ying, Z., Chotimah, S., Bernard, M., Zulfah, \& Astuti. (2020). Hawgent dynamic mathematic software as mathematics learning media for teaching quadratic functions. Journal of Physics: Conference Series, 1592(1). https://doi.org/10.1088/1742-6596/1592/1/012079

Wijaya, Tommy Tanu, Ying, Z., \& Purnama, A. (2020). The empirical research of hawgent dynamic mathematics technology integrated into teaching. Journal Cendekia: Jurnal Pendidikan Matematika, 04(01), 144-150.

Zhang, L., Zhou, Y., \& Wijaya, T. T. (2020). Hawgent dynamic mathematics software to improve problem-solving ability in teaching triangles. Journal of Physics: Conference Series, 1663(1). https://doi.org/10.1088/1742-6596/1663/1/012069

Zazkis, R., dan Liljedahl, P. 2004. Understanding Primes: The Role of Representation. Journal for Research in Mathematics Education 2004. Vol.35, No. 3, 164-186. 